\title{
Dynamics of organic carbon losses by water erosion after biocrust removal
}

\author{
Yolanda Cantón $^{1 *}$, Jose Raúl Román ${ }^{1}$, Sonia Chamizo ${ }^{1}$, Emilio Rodríguez-Caballero ${ }^{1}$, María José Moro ${ }^{2}$ \\ ${ }^{1}$ Department of Agronomy, Higher Polytechnic School and Experimental Science College, University of Almeria, Ctra. Sacramento s/n La \\ Cañada de San Urbano, 04120 Almería, Spain. \\ ${ }^{2}$ Department of Ecology, University of Alicante, Ctra de San Vicente del Raspeig, sn. 03690 San Vicente del Raspeig, Alicante, Spain. \\ * Corresponding author. E-mail: ycanton@ual.es
}

\begin{abstract}
In arid and semiarid ecosystems, plant interspaces are frequently covered by communities of cyanobacteria, algae, lichens and mosses, known as biocrusts. These crusts often act as runoff sources and are involved in soil stabilization and fertility, as they prevent erosion by water and wind, fix atmospheric $\mathrm{C}$ and $\mathrm{N}$ and contribute large amounts of $\mathrm{C}$ to soil. Their contribution to the $\mathrm{C}$ balance as photosynthetically active surfaces in arid and semiarid regions is receiving growing attention. However, very few studies have explicitly evaluated their contribution to organic carbon (OC) lost from runoff and erosion, which is necessary to ascertain the role of biocrusts in the ecosystem C balance. Furthermore, biocrusts are not resilient to physical disturbances, which generally cause the loss of the biocrust and thus, an increase in runoff and erosion, dust emissions, and sediment and nutrient losses. The aim of this study was to find out the influence of biocrusts and their removal on dissolved and sediment organic carbon losses. One-hour extreme rainfall simulations $\left(50 \mathrm{~mm} \mathrm{~h}^{-1}\right)$ were performed on small plots set up on physical soil crusts and three types of biocrusts, representing a development gradient, and also on plots where these crusts were removed from. Runoff and erosion rates, dissolved organic carbon (DOC) and organic carbon bonded to sediments $\left(\mathrm{S}_{\mathrm{d}} \mathrm{OC}\right)$ were measured during the simulated rain. Our results showed different $\mathrm{S}_{\mathrm{d}} \mathrm{OC}$ and $\mathrm{DOC}$ for the different biocrusts and also that the presence of biocrusts substantially decreased total organic carbon (TOC) (average $1.80 \pm 1.86 \mathrm{~g} \mathrm{~m}^{-2}$ ) compared to physical soil crusts $\left(7.83 \pm 3.27 \mathrm{~g} \mathrm{~m}^{-2}\right)$. Within biocrusts, TOC losses decreased as biocrusts developed, and erosion rates were lower. Thus, erosion drove TOC losses while no significant direct relationships were found between TOC losses and runoff. In both physical crusts and biocrusts, $\mathrm{DOC}$ and $\mathrm{S}_{\mathrm{d}} \mathrm{OC}$ concentrations were higher during the first minutes after runoff began and decreased over time as nutrient-enriched fine particles were washed away by runoff water. Crust removal caused a strong increase in water erosion and TOC losses. The strongest impacts on TOC losses after crust removal occurred on the lichen plots, due to the increased erosion when they were removed. DOC concentration was higher in biocrust-removed soils than in intact biocrusts, probably because OC is more strongly retained by BSC structures, but easily blown away in soils devoid of them. However, $\mathrm{S}_{\mathrm{d}} \mathrm{OC}$ concentration was higher in intact than removed biocrusts associated with greater OC content in the top crust than in the soil once the crust is scraped off. Consequently, the loss of biocrusts leads to OC impoverishment of nutrient-limited interplant spaces in arid and semiarid areas and the reduction of soil OC heterogeneity, essential for vegetation productivity and functioning of this type of ecosystems.
\end{abstract}

Keywords: Biological soil crust; Dissolved OC; Sediment OC; Runoff; Biocrust disturbance; Physical crust.

\section{INTRODUCTION}

The widespread concern for global warming due to the greenhouse effect in recent decades has caused growing interest in accurate knowledge of the carbon cycle in different ecosystems, and has become one of the main current scientific challenges. However, there are scarce data on the $\mathrm{C}$ cycle and its controlling drivers in arid and semiarid ecosystems, despite their important worldwide representation (more than $35 \%$ of the Earth's surface) which suggests that such ecosystems could play a very important role in the global carbon cycle. This is probably due to the perception that a scarce, scattered plant cover, along with apparently bare surfaces, has a low positive, null or negative annual $\mathrm{CO}_{2}$ balance. However, these lands are often not barren at all, but colonized by a complex community of cyanobacteria, bacteria, green algae, microfungi, lichens and mosses, which together are known as biological soil crusts or biocrusts. In some ecosystems, they represent the main cover, and all of them are able to fix $\mathrm{CO}_{2}$, even in extreme conditions for plants. Thus the contribution of photosynthetically active biocrust surfaces to the $\mathrm{C}$ balance in arid and semiarid regions can be very significant, and consequently, several recent studies have evaluated their influence on the soil-atmosphere $\mathrm{CO}_{2}$ exchange (vertical fluxes). However, even though biocrusts are usually recognized as important sources of runoff for adjacent vegetation, very few studies have explicitly evaluated their contribution to $\mathrm{C}$ exported by runoff and erosion (horizontal fluxes), which is necessary to ascertain the real role of biocrusts in the ecosystem $\mathrm{C}$ balance. It is well known that in arid and semiarid ecosystems, as consequence of the scarce plant cover, the wide extension of crusted soils and torrential rainfall, runoff plays a crucial role in nutrient loss and redistribution (Ludwig et al., 1997). Although poorly quantified, some authors have estimated carbon losses, indirectly (Forrester et al., 2006; Litton et al., 2004) or directly (Almagro et al., 2010) through erosion and leaching, in different ecosystems and found that the effect within the annual $\mathrm{C}$ balance was insignificant at the ecosystem level. However, in semiarid ecosystems with degraded soils and low soil organic carbon, even with moderate erosion rates and soils poor in OC, the contribution of OC losses from runoff and erosion can be considerable (Martínez-Mena et al., 2008; Quinton and Pomeroy., 2006). Ecosystems with a high biocrust cover are within this group of ecosystems. Considering that these crusts may often represent up to $70 \%$ of ground cover (Belnap et al., 2005; Chamizo et al., 2012a; Miralles-Mellado et al., 2011) and over $60 \%$ of rainfall falling on a biologically crusted surface becomes runoff (Cantón el al., 2001; Chamizo et al., 2012a; Rodríguez-Caballero et al., 2013), which is able to 
export $\mathrm{OC}$ from biocrust constituents, suspended and dissolved by runoff and mobilized sediments, the mobilization of $\mathrm{OC}$ from biocrusts may be quite significant. Exported $\mathrm{OC}$ is often trapped by vegetated patches located downstream of crusted areas, providing an important nutrient supply essential to maintain primary productivity and biological activity in systems that are strongly limited by water and soil nutrient availability (Kidron, 2014; Whitford, 2002). Li et al. (2008) reported that over $75 \%$ of sediments, $63 \%$ of soil carbon, $74 \%$ of nitrogen and $45 \sim 73 \%$ of dissolved nutrients from crust patches released by runoff were delivered to shrub patches. However, biocrusts may sometimes be directly connected to stream networks, and others the magnitude of the runoff event overwhelms the capacity of vegetated patches for trapping OC in runoff and sediments (Rodríguez-Caballero et al., 2014), leading to important loss of OC.

Biocrust composition and cover affect OC content in underlying soils (Chamizo et al., 2012b), and are also factors that have been demonstrated to affect runoff and water erosion and are therefore expected to strongly influence OC mobilization. Chamizo et al. (2012a) found higher infiltration in biocrusts than in physical crusts, and as a general trend, an increase in infiltration with biocrust development, that is, as cyanobacteria biomass increased and later successional species, such as lichens and mosses, colonized the soil. However, exceptions to this pattern are described by the same authors, specifically in fine textured sites, where crustose and squamulose lichen crusts, although more developed and rougher than the other biocrust types, generated higher runoff rates as a consequence of their greater hydrophobicity and pore clogging (Kidron, 2014; Kidron et al., 1999; Rodríguez-Caballero et al., 2013). Thus, biocrusts can considerably influence hydrophysical parameters and water flow in soils, mainly due to soil water repellency (Lichner et al., 2012).

An important biocrust feature that should be highlighted is their low resilience to physical disturbance and increasing human activity, such as livestock grazing, off-road vehicles, and trampling in arid and semiarid ecosystems (Warren, 2003). Disturbance can cause the loss of biocrust biomass and cover and species diversity, and the replacement of well-developed biocrusts composed of a rich community of a diversity of species of cyanobacteria, lichens and mosses by a simple community composed of a few cyanobacteria species (Belnap and Eldridge, 2003). Biocrust disturbances bring on lower infiltration, OC fixation and soil OC concentrations, less soil stability and higher dust emissions, and loss of nutrients. From the scant published information, it can be deduced that the strongest impact of biocrust disturbance on water processes and sediment and nutrient losses take place during the first rains after disturbance. An initial increase in infiltration immediately after biocrust removal has been described by some authors (Chamizo et al., 2012a; Eldridge et al., 2000) followed by a fast decrease over time attributed to the appearance of a physical soil crust (Chamizo et al., 2012a). Erosion rates increase over 70-fold under very intense rainfall immediately following removal of developed biocrusts (Chamizo et al., 2012a), and C and $\mathrm{N}$ losses in sediments can be over 4 times higher from disturbed than intact plots (Barger et al., 2006). Moreover, Li et al. (2008) showed how disturbance of biocrust patches led to uniform distribution of water over the whole slope and reduction in flow of vital resources from crust patches to shrub patches, which is crucial for the maintenance of plant productivity and vegetation cover.

For all the above reasons, evaluation of the mobilization of OC from biocrusts and its subsequent redistribution, especially during high-magnitude runoff events, is necessary to elucidate the biocrust contribution to ecosystem $\mathrm{C}$ cycle processes affecting $\mathrm{C}$ uptake and release. In this paper we aim to ascertain the influence of biocrusts and their disturbance on loss of dissolved and sediment OC. Our specific goals were: 1) to find out the influence of different crust types, including physical crusts and biocrusts following a development gradient, on OC mobilization, distinguishing dissolved OC and $\mathrm{OC}$ transported in sediments, 2) evaluate how disturbance of the crust (crust removal) affects OC mobilization, and 3) characterize the dynamics of $\mathrm{OC}$ mobilization during the course of intense rainfall.

\section{MATERIAL AND METHODS Study site}

Organic carbon content in runoff water and sediments from soils covered by different crust types were measured in the El Cautivo experimental site, located in the Tabernas Desert (Almeria, SE Spain) (Fig. 1). The area is a semiarid badlands catchment surrounded by the Gador, Nevada, Filabres and Alhamilla Mountain Ranges. The basin is mainly filled by gypsiferous mudstone and calcareous sandstone. Climate is semiarid warm Mediterranean with very dry summers and rain mostly in autumn and winter. The average annual temperature is $18^{\circ} \mathrm{C}$ and the average annual rainfall is $235 \mathrm{~mm}$, with high interannual variability (coefficient of variation 39\%) (Cantón et al., 2002). Annual potential evapotranspiration is $1500 \mathrm{~mm}$, so there is a high annual water deficit. Silt is the dominant particle size, and soils are classified as Epileptic, Endoleptic or Calcaric Regosols and Eutric Gypsisols (Cantón et al., 2003). The landscape is characterized by asymmetric hillslopes, so ground cover is strongly controlled by topographic attributes (Cantón et al., 2004). NE-facing slopes, with gradients ranging from $10^{\circ}$ to $30^{\circ}$, are heavily covered by biocrusts, frequently consisting of crustose and squamulose lichens, interspersed with vegetated patches which become denser on the pediments. SW-facing slopes, ranging from $30^{\circ}$ to $70^{\circ}$, are mainly covered by physical crusts, which usually form over the bare marl regolith (Cantón et al., 2002). Thus, most soil in the interplant spaces is covered by either physical crusts (30\%), mainly structural crusts formed by raindrop impact, or biocrusts (50\%) composed of rich communities with a high diversity of species. Previous studies have identified four main soil crust types, from less to higher crust development, in this area (Chamizo et al., 2012a; Lázaro et al., 2008) (Fig. 1): 1) a physical soil crust, 2) an incipient or little-developed cyanobacteria crust, 3) a dark well-developed cyanobacteria crust, which also contains numerous pioneer lichens, including Placynthium nigrum, Collema spp., Endocarpon pusillum, Catapyrenium rufescens and Fulgensia spp., and 4) a light-colored lichen crust mainly composed of the Diploschistes diacapasis and Squamarina lentigera species of lichens. Biocrust cover, surface roughness and OC content in the top crust and the 1-cm soil layer underneath the four crust types are summarized in Table 1. Surface roughness was measured using the chain method, using a $50-\mathrm{cm}$ long chain with $0.3-\mathrm{cm}$ long links. Three roughness transects were made in the direction of the maximum slope and another three transects, perpendicular to the previous one. Data from both transects were averaged. Four samples of each crust type and its underlying soil were collected, and organic carbon content in top crust and the 1-cm soil layer underneath the four crust types were determined by the Walkley and Black method modified by Mingorance et al. (2007). 

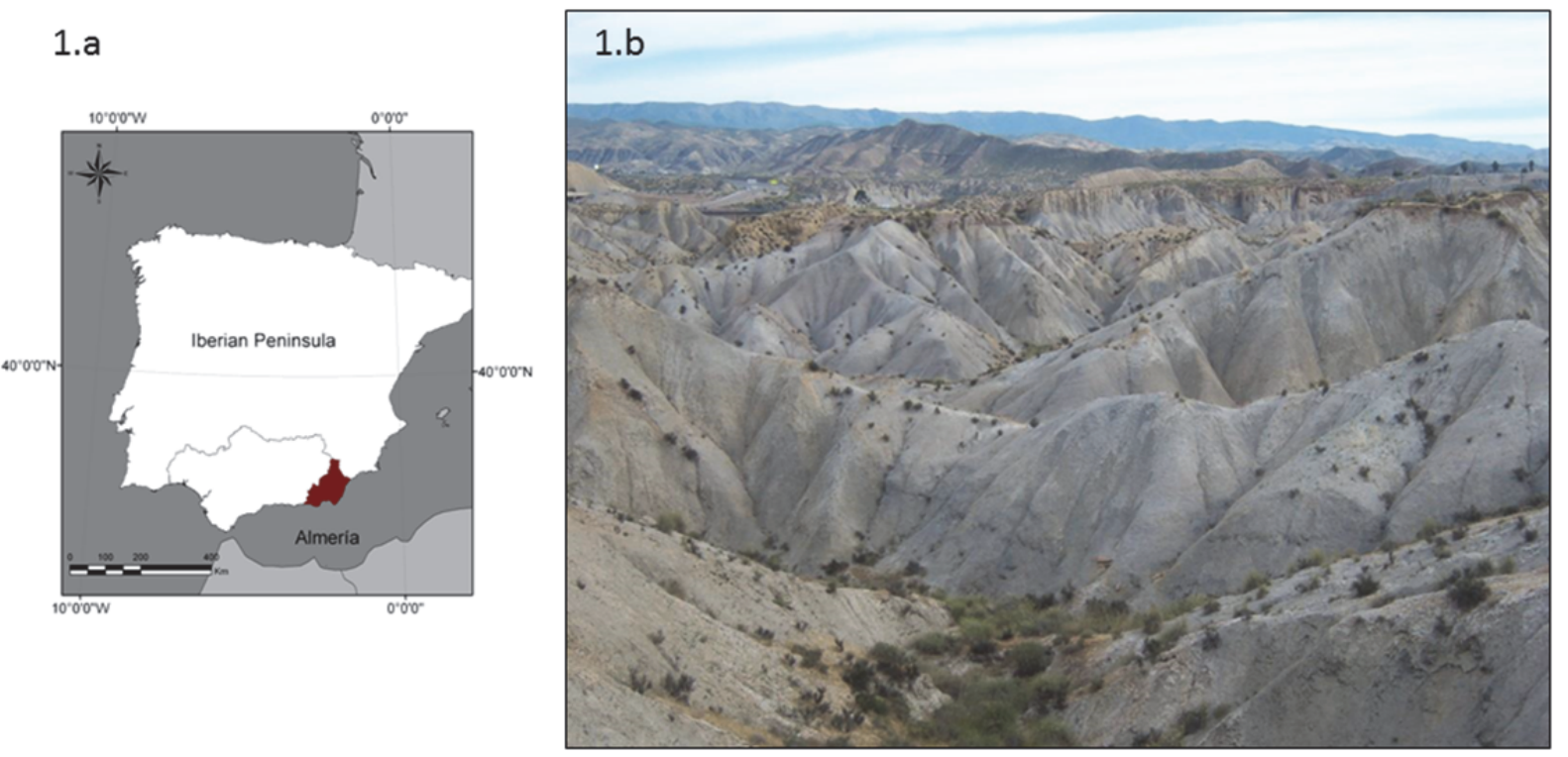

1.c
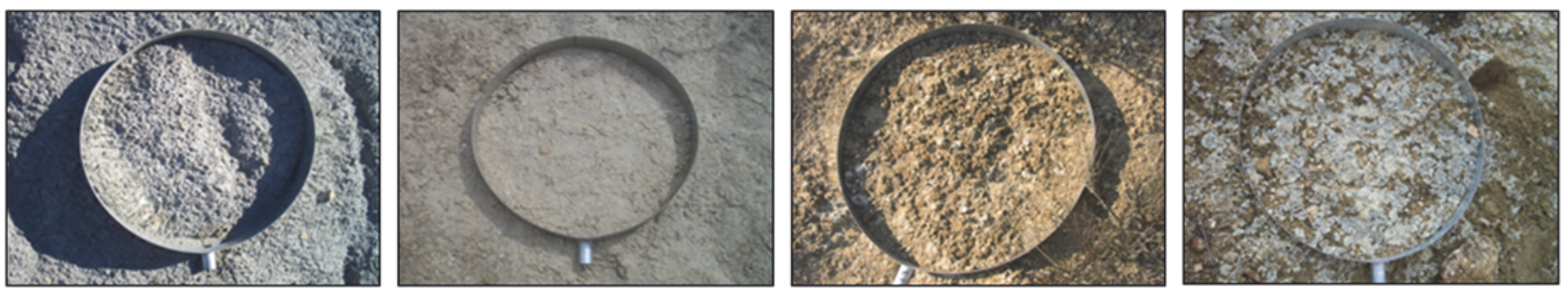

Fig. 1. El Cautivo experimental area location (Figure 1a); detailed of the study area (Figure 1b); runoff plots over the different crust types (from left to right): physical soil crust, incipient cyanobacteria crust, well-developed cyanobacteria crust and lichen crust (Figure 1c).

Table 1. Mean value of cyanobacteria fractional cover, lichen fractional cover, roughness, crust organic carbon and organic carbon in the layer just below the crust, for the four different plots representing each different crust type (physical soil crust, incipient cyanobacteria crust, well-developed cyanobacteria crust and lichen crust).

\begin{tabular}{c|c|c|c|c|c}
\hline & $\begin{array}{c}\text { Cyanobacteria cover } \\
(\%)\end{array}$ & $\begin{array}{c}\text { Lichen cover } \\
(\%)\end{array}$ & Roughness index & $\begin{array}{c}\text { Crust organic carbon } \\
\text { content } \\
(\%)\end{array}$ & $\begin{array}{c}\text { l cm soil-layer organic } \\
\text { carbon content } \\
(\%)\end{array}$ \\
\hline Physical crust & 0 & 0 & $1.10 \pm 0.05$ & $0.54 \pm 0.10$ & $0.60 \pm 0.09$ \\
\hline $\begin{array}{c}\text { Incipient cyanobac- } \\
\text { teria crust }\end{array}$ & $27.5 \pm 17.7$ & $3.7 \pm 0.6$ & $1.04 \pm 0.05$ & $0.62 \pm 0.11$ & $0.64 \pm 0.17$ \\
\hline $\begin{array}{c}\text { Well-developed } \\
\text { cyanobacteria crust }\end{array}$ & $84.5 \pm 4.3$ & $5.9 \pm 5.1$ & $1.10 \pm 0.06$ & $1.27 \pm 0.55$ & $1.13 \pm 0.34$ \\
\hline Lichen crust & $15.5 \pm 10.2$ & $77.8 \pm 10.8$ & $1.20 \pm 0.01$ & $2.73 \pm 1.54$ & $0.88 \pm 0.10$ \\
\hline
\end{tabular}

*Roughness index: Ratio between chain length $(50 \mathrm{~cm})$ and horizontal length when placed on the crust

\section{Rainfall simulation experiments}

Runoff and erosion yield were measured under simulated rainfall on soils covered by the crust types described above. Four pairs of $1 \mathrm{~m} \mathrm{x} 1 \mathrm{~m}$ plots of each crust type were selected. All runoff plots were located on N-W facing hillslopes. In each pair, one plot was left undisturbed and the crust was scraped off (around $0.5 \mathrm{~cm}$ corresponding to crust thickness) the other. In the center of the plots, a $0.25-\mathrm{m}^{2}$ circular steel ring with a hole at its lowest point on the slope to drain runoff was inserted (Fig. 1). One rainfall simulation was carried out on each plot using the rainfall simulator designed by Calvo-Cases et al. (1988). It consists of a sprinkler mounted on a 2.10-m-high structure that generates rain over a $0.25 \mathrm{~m}^{2}$ area at a constant intensity of $50 \mathrm{~mm} \mathrm{~h}^{-1}$. Rainfall simulations performed lasted 1 hour. Runoff volume was measured with a test tube at set intervals throughout the simulation. During the first half of the rainfall simulation, when higher variability in OC mobilization was expected, four runoff samples were collected (1-13 min, 13-20 min, 20-26 min, 26-30 min), and one combined sample of water from $35-37,41,47$ and 56 minutes was collected during the last half hour of the rainfall simulation. Sediment 
content and water and sediment OC were determined in these samples.

\section{Organic carbon determination}

In the laboratory, runoff samples were filtered through a $0.75 \mu \mathrm{m}$ millipore filter to separate sediments from the water. Sediments were dried in an oven at $70^{\circ} \mathrm{C}$ and weighed. After sample homogenization, a small quantity of $0.1 \mathrm{~g}$ was taken and used for analysis of $\mathrm{OC}$ in sediments. For analysis of $\mathrm{OC}$ in water, an aliquot of $10 \mathrm{ml}$ was dried in an oven at $60^{\circ} \mathrm{C}$ and $\mathrm{OC}$ was then measured in the residue remaining in the vial. Dissolved organic carbon (DOC) and sediment organic carbon $\left(\mathrm{S}_{\mathrm{d}} \mathrm{OC}\right)$ were determined using the Walkley and Black method modified by Mingorance et al. (2007), consisting of organic matter oxidation by sulphuric acid and potassium dichromate and later measurement of the absorbance in a spectrophotometer at $590 \mathrm{~nm}$

\section{Data analysis}

From DOC concentrations $\left(\mathrm{mg} \mathrm{L}^{-1}\right)$ and runoff rates $\left(\mathrm{L} \mathrm{m}^{-2}\right)$, DOC mobilization $\left(\mathrm{g} \mathrm{m}^{-2}\right)$ was estimated. From $\mathrm{S}_{\mathrm{d}} \mathrm{OC}\left(\mathrm{mg} \mathrm{g}^{-1}\right)$ concentrations and sediment yield $\left(\mathrm{g} \mathrm{m}^{-2}\right), \mathrm{S}_{\mathrm{d}} \mathrm{OC}$ mobilization $\left(\mathrm{g} \mathrm{m}^{-2}\right)$ was obtained on each plot. Total organic carbon (TOC) was calculated as the sum of DOC and $\mathrm{S}_{\mathrm{d}} \mathrm{OC}$. General linear models were used to analyze the effect of crust type and removal on DOC, $\mathrm{S}_{\mathrm{d}} \mathrm{OC}$ and TOC mobilization. Interaction of factors was also considered in the analysis. Significant differences among crust types and between the control and removal treatment for each crust type were analyzed using the Fisher's LSD post hoc test. The significance level was set at $p<0.05$. The influence of runoff and erosion on TOC loss was assessed by linear regression analysis, in which TOC was the dependent variable and runoff rate and erosion rate were the independent variables. Statistical analyses were done using STATISTICA 8.0 (StatSoft, Inc., Tulsa, Oklahoma, USA).

\section{RESULTS}

The analysis of the effects of biocrust type and removal on OC mobilization (DOC, $\mathrm{S}_{\mathrm{d}} \mathrm{OC}$ and TOC) showed that the type of biocrust had a significant influence on DOC, $\mathrm{S}_{\mathrm{d}} \mathrm{OC}$, and TOC (Table 2). Removal significantly influenced $\mathrm{S}_{\mathrm{d}} \mathrm{OC}$ and TOC, but had no significant effect on DOC. There was also a significant interaction between the biocrust type and removal for both $\mathrm{S}_{\mathrm{d}} \mathrm{OC}$ and TOC, meaning that biocrust removal had varying effects depending on the biocrust type.

\section{Influence of biocrust type on OC mobilization}

Table 3 shows mean DOC, $\mathrm{S}_{\mathrm{d}} \mathrm{OC}$ and TOC in undisturbed and removed biocrusts. It can be observed in the OC exported from undisturbed crusts that the highest DOC was recorded in the physical soil crust plots. This was significantly different from the incipient cyanobacteria biocrusts, which showed the lowest DOC losses. DOC was intermediate on developed cyanobacteria and lichen biocrusts. Mobilization of OC bonded to sediments $\left(\mathrm{S}_{\mathrm{d}} \mathrm{OC}\right)$ was highest on physical soil crusts, which significantly differed from exported $\mathrm{S}_{\mathrm{d}} \mathrm{OC}$ on biocrusts. $\mathrm{S}_{\mathrm{d}} \mathrm{OC}$ decreased with biocrust development (incipent cyanobacteria $>$ developed cyanobateria $>$ lichen).

$\mathrm{S}_{\mathrm{d}} \mathrm{OC}$ losses represented $94 \%$ to $64 \%$ of TOC losses, and were considerably greater than DOC losses in all crusts. This means that TOC mobilization was driven by $\mathrm{S}_{\mathrm{d}} \mathrm{OC}$, and this relationship was stronger on physical soil crusts and incipient cyanobacteria biocrusts, in which $\mathrm{S}_{\mathrm{d}} \mathrm{OC}$ represented $91 \%$ and $94 \%$ of TOC, respectively. This result explains why, according to the general linear model, the same influencing factors were found for $\mathrm{S}_{\mathrm{d}} \mathrm{OC}$ and TOC, (Table 2). It is interesting to note that DOC losses from the undisturbed developed biocrust plots, (cyanobacteria and lichen) contributed much more $(17 \%$ and $36 \%$ respectively) to TOC losses than physical and incipient crusts (5\% and $9 \%$ respectively).

Table 2. Effects of the crust type (physical soil crust, incipient cyanobacteria, developed cyanobacteria and lichen crust) and treatment (unaltered crust and removed crust) on: dissolved organic carbon (DOC), sediment organic carbon $\left(\mathrm{S}_{\mathrm{d}} \mathrm{OC}\right)$ and total organic carbon (TOC). Significant differences were established at $\mathrm{p}<0.05$.

\begin{tabular}{ccccccc}
\hline & \multicolumn{2}{c}{ DOC } & \multicolumn{2}{c}{$\mathrm{S}_{\mathrm{d}} \mathrm{OC}$} & \multicolumn{3}{c}{ TOC } \\
\hline & $\mathrm{F}$ & $\mathrm{P}$ & $\mathrm{F}$ & $\mathrm{P}$ & $\mathrm{F}$ & $\mathrm{P}$ \\
\hline Type of crust & 7.256 & 0.002 & 8.154 & 0.00 & 7.280 & 0.002 \\
Treatment & 3.113 & 0.093 & 19.15 & 0.00 & 14.47 & 0.001 \\
Type of crust*treatment & 0.909 & 0.455 & 18.6 & 0.00 & 8.903 & 0.001 \\
\hline
\end{tabular}

Table 3. Mean value of dissolved organic carbon (DOC), sediment organic carbon $\left(\mathrm{S}_{\mathrm{d}} \mathrm{OC}\right)$ and total organic carbon (TOC), for the four different plots representing each different crust type (physical soil crust, incipient cyanobacteria crust, well-developed cyanobacteria crust and lichen crust) and treatments (unaltered and removed).

\begin{tabular}{|c|c|c|c|c|c|c|c|c|}
\hline \multirow[t]{2}{*}{ Crust type } & \multicolumn{2}{|c|}{$\operatorname{DOC}\left(\mathrm{g} \mathrm{m}^{-2}\right)$} & \multicolumn{2}{|c|}{$\mathrm{S}_{\mathrm{d}} \mathrm{OC}\left(\mathrm{g} \mathrm{m}^{-2}\right)$} & \multicolumn{2}{|c|}{$\operatorname{TOC}\left(\mathrm{g} \mathrm{m}^{-2}\right)$} & \multicolumn{2}{|c|}{ DOC/TOC } \\
\hline & Unaltered & Removed & Unaltered & Removed & Unaltered & Removed & Unaltered & Removed \\
\hline Physical crust & $0.47 \pm 0.39^{\mathrm{a}}$ & $1.50 \pm 1.30^{\mathrm{a}}$ & $7.36 \pm 2.89^{a}$ & $4.60 \pm 1.60^{b}$ & $7.83 \pm 3.27^{\mathrm{a}}$ & $6.10 \pm 3.18^{b}$ & $5.22 \pm 2.70$ & $24.5 \pm 19.2$ \\
\hline $\begin{array}{l}\text { Incipient cyano- } \\
\text { bacteria crust }\end{array}$ & $0.18 \pm 0.15^{\mathrm{b}}$ & $1.16 \pm 2.24^{\mathrm{b}}$ & $3.25 \pm 2.05^{\mathrm{b}}$ & $4.41 \pm 2.41^{\mathrm{b}}$ & $3.43 \pm 2.16^{\mathrm{b}}$ & $5.57 \pm 4.45^{\mathrm{b}}$ & $5.24 \pm 10.41$ & $20.8 \pm 15.6$ \\
\hline Cyanobacteria crust & $0.21 \pm 0.12^{\mathrm{ab}}$ & $0.28 \pm 0.20^{\mathrm{b}}$ & $1.00 \pm 1.04^{b}$ & $3.69 \pm 1.96^{b}$ & $1.21 \pm 1.15^{\mathrm{b}}$ & $3.97 \pm 2.01^{b}$ & $17.4 \pm 11.0$ & $7.05 \pm 4.18$ \\
\hline Lichen crust & $0.26 \pm 0.08^{\mathrm{ab}}$ & $1.13 \pm 2.01^{\mathrm{b}}$ & $0.47 \pm 0.17^{b}$ & $10.7 \pm 2.2^{\mathrm{a}}$ & $0.73 \pm 0.40^{b}$ & $11.8 \pm 5.36^{\mathrm{a}}$ & $36.0 \pm 10.0$ & $9.6 \pm 14.2$ \\
\hline
\end{tabular}

*Letters indicate significant differences within each column (among crust types). Numbers in bold indicate significant differences between treatments for each crust type. 

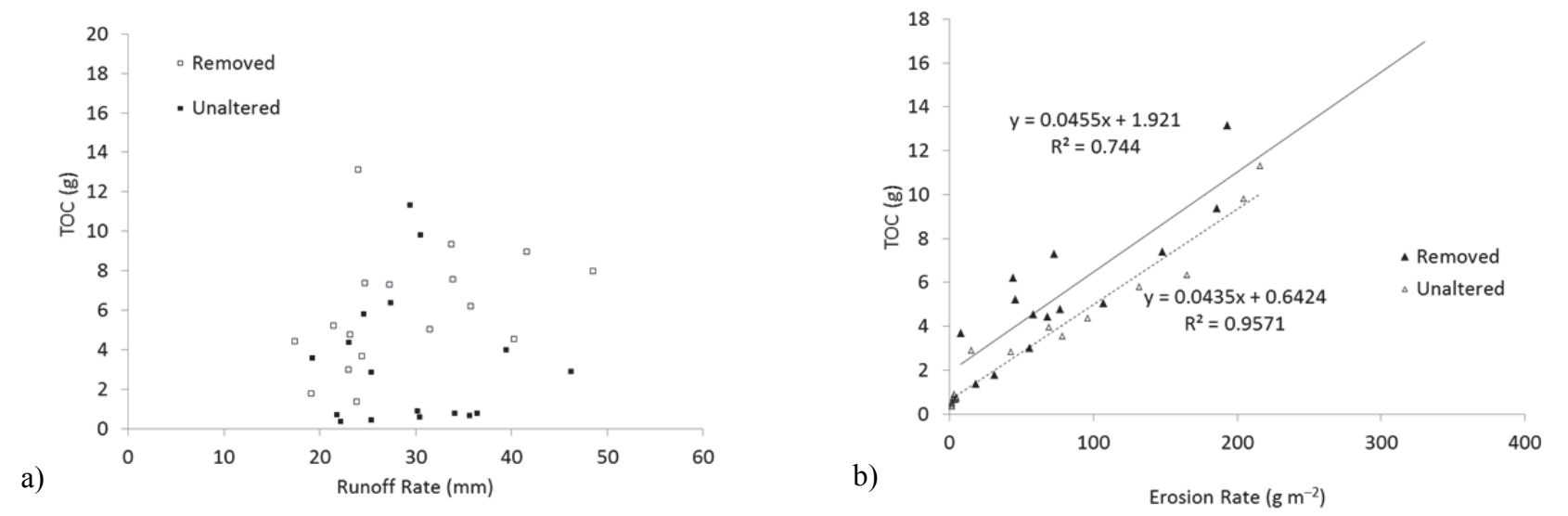

Fig. 2. Relationship between total organic carbon (TOC) and runoff rate (Figure 2a); relationship between total organic carbon (TOC) and erosion rate (Figure $2 b$ ).

Fig. 2 shows the relationship between total runoff (L) leaving each plot and TOC $(\mathrm{g})$ during the simulated rainfall. Analysis of the relationship between total runoff and TOC for all undisturbed crusts (Fig. 2a) shows that TOC loss was not directly driven by runoff $(p=0.81)$. Extending the analysis to consider the relationships between runoff and TOC in each type of crust and also distinguishing undisturbed and removed crusts, the relationships remained insignificant on almost all plots. On the contrary, a positive significant relationship between eroded sediment and TOC $\left(\mathrm{r}^{2}=0.96, \mathrm{p}<0.05\right)$ was found across all plots (Fig. 2b).

Regarding DOC and $\mathrm{S}_{\mathrm{d}} \mathrm{OC}$ concentrations, event average DOC concentrations were similar on biocrusts $\left(7.6 \pm 2.7 \mathrm{mg} \mathrm{L}^{-1}\right.$, $6.1 \pm 1.6 \mathrm{mg} \mathrm{L}^{-1}$ and $6.96 \pm 5.92 \mathrm{mg} \mathrm{L}^{-1}$ in lichen, cyanobacteria and incipient cyanobacteria, respectively), but higher for physical soil crusts $\left(16.5 \pm 12.5 \mathrm{mg} \mathrm{L}^{-1}\right)$. On the other hand, $\mathrm{S}_{\mathrm{d}} \mathrm{OC}$ concentrations were considerably higher in developed biocrusts $\left(38.3 \pm 9.3 \mathrm{mg} \mathrm{g}^{-1}\right.$ in cyanobacteria and $47.8 \pm 3 \mathrm{mg}$ $\mathrm{g}^{-1}$ in lichen) than in incipient cyanobacteria biocrusts $(19.7 \pm$ $\left.16.2 \mathrm{mg} \mathrm{g}^{-1}\right)$, and much higher than in physical crusts $(11.3 \pm$ $\left.0.6 \mathrm{mg} \mathrm{g}^{-1}\right)$.

However, the significantly higher total erosion in incipient cyanobacteria and physical crusts (Fig. 3) is responsible for greater $\mathrm{S}_{\mathrm{d}} \mathrm{OC}$ and, consequently, TOC losses, in these crusts than in more developed cyanobacteria and lichen biocrusts.

\section{Influence of biocrust removal on OC mobilization}

The removal of the crust had different effects on DOC and $\mathrm{S}_{\mathrm{d}} \mathrm{OC}$ depending on the crust type. The removal of the physical crust significantly increased DOC (DOC losses were tripled after crust removal), but had an opposite effect on $\mathrm{S}_{\mathrm{d}} \mathrm{OC}$, which significantly decreased after crust removal (Table 3 ). Biocrust removal increased DOC losses, however, they were not significantly different from the intact biocrusts. Removal of the biocrusts caused a significant increase in $\mathrm{S}_{\mathrm{d}} \mathrm{OC}$ losses in all biocrusts, except in the incipient cyanobacteria crust, and the impact was especially strong on lichens where $\mathrm{S}_{\mathrm{d}} \mathrm{OC}$ losses increased more than one order of magnitude. In fact, the highest TOC after biocrust removal was recorded on lichen plots.

\section{Dynamics of OC losses during rainfall}

Fig. 3 shows DOC and $\mathrm{S}_{\mathrm{d}} \mathrm{OC}$ (together $=$ TOC) losses at the five runoff sampling points during simulated rainfall in one representative plot of each crust type.
The high runoff and erosion rates recorded on physical soil crusts (Fig. 3a) led to the highest TOC losses, despite their low OC content (Table 1) and low OC concentrations in both, runoff (Fig. 4a) and sediments (Fig. 4b). It is worth mentioning the high DOC concentration at the beginning of the runoff event (38 $\mathrm{mg} \mathrm{L}^{-1}$ from the beginning of rainfall to minute 13) on the intact physical soil crust, which fell drastically to $2 \mathrm{mg} \mathrm{L}^{-1}$ in the second sampling (from minute 13 to 20 of rainfall). After crust removal, OC dynamics in the four physical soil crust plots showed increased infiltration, and therefore, less erosion during the first half of the rainfall experiment. As a consequence of lowered runoff, DOC concentration was an order of magnitude higher than in intact physical crusts at the beginning of the rainfall event (Fig. 4a), thus enhancing DOC losses (Fig. 3a), while $\mathrm{S}_{\mathrm{d}} \mathrm{OC}$ concentrations did not undergo any substantial change, and therefore, $\mathrm{S}_{\mathrm{d}} \mathrm{OC}$ and TOC went down, because there was less erosion (Table 3). Although scraping the crust enhanced infiltration in the beginning, after several minutes of intense rainfall, the scraped soils were sealed again by raindrop impact, lowering infiltration rates on these surfaces during the second half of rainfall simulation (Fig. 3b). Erosion rates were slightly lower and also $\mathrm{S}_{\mathrm{d}} \mathrm{OC}$ and TOC (Fig. 3b).

As described above, unaltered incipient cyanobacteria crust responded to rainfall with low DOC concentrations but high $\mathrm{S}_{\mathrm{d}} \mathrm{OC}$ concentrations. As a result of the high $\mathrm{S}_{\mathrm{d}} \mathrm{OC}$ concentrations and high erosion rates recorded on these plots (Fig. 3c), these biocrusts accounted for the highest $\mathrm{S}_{\mathrm{d}} \mathrm{OC}$ and TOC losses of the unaltered biocrusts studied. Although DOC and $\mathrm{S}_{d} \mathrm{OC}$ concentrations did not significantly increase during the simulated rainfall after crust removal (between 8.67 and $11.23 \mathrm{mg} \mathrm{L}^{-1}$ for DOC and 22.09 and $12.49 \mathrm{mg} \mathrm{L}^{-1}$ for $\mathrm{S}_{\mathrm{d}} \mathrm{OC}$ ) (Fig. 3d), $\mathrm{S}_{\mathrm{d}} \mathrm{OC}$ losses increased as a consequence of the increase in sediment yield.

In a typical undisturbed developed biocrust (cyanobacteria and lichen) DOC concentration during the first 13 minutes of rainfall $\left(16\right.$ and $\left.15 \mathrm{mg} \mathrm{L}^{-1}\right)$ was higher than DOC concentration after 20 minutes of rainfall $\left(6\right.$ and $\left.10 \mathrm{mg} \mathrm{L}^{-1}\right)$. DOC concentration in these plots gradually decreased with rainfall because of dilution by the increase in runoff (Fig. 4a). Sediments were also more highly enriched in OC in the first few minutes of rainfall (50 and $52 \mathrm{~g} \mathrm{~kg}^{-1}$ for lichen and cyanobacteria, respectively) than they were afterwards (32 and $29 \mathrm{mg} \mathrm{g}^{-1}$ for lichen and cyanobacteria, respectively) (Fig. 4b). Although $\mathrm{S}_{\mathrm{d}} \mathrm{OC}$ concentrations throughout rainfall were higher in both developed biocrusts than in physical soil crusts, $\mathrm{S}_{\mathrm{d}} \mathrm{OC}$ and TOC losses were significantly lower due to lower sediment 

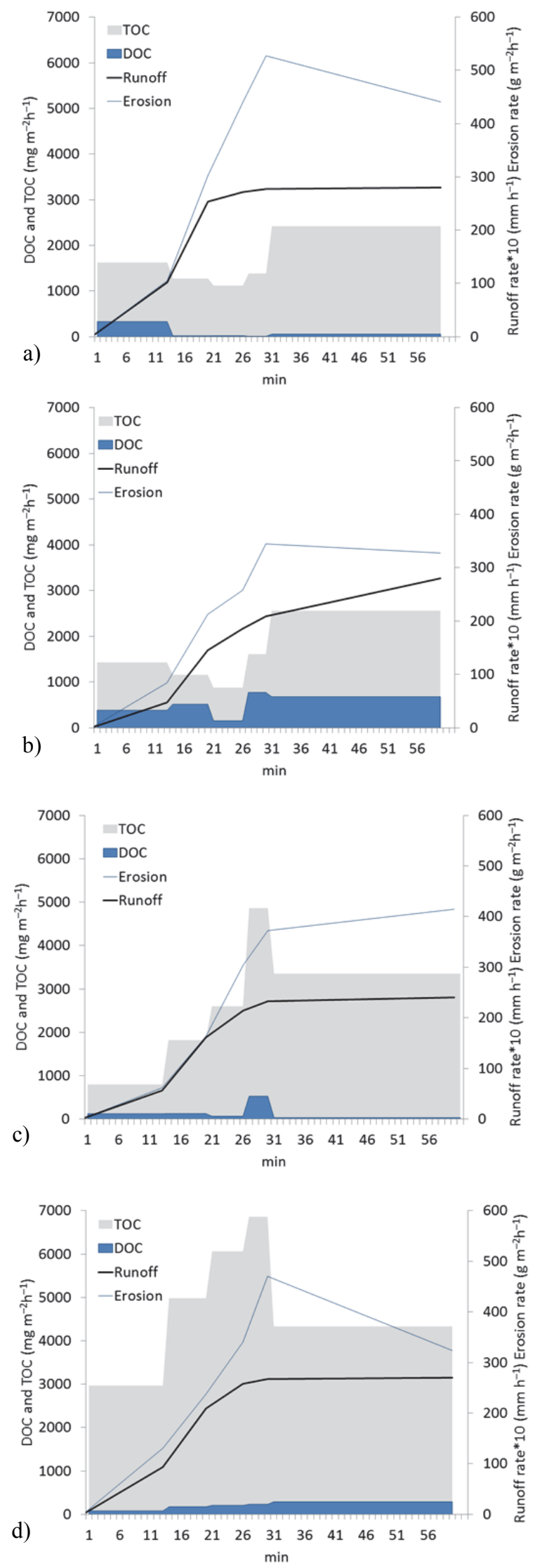
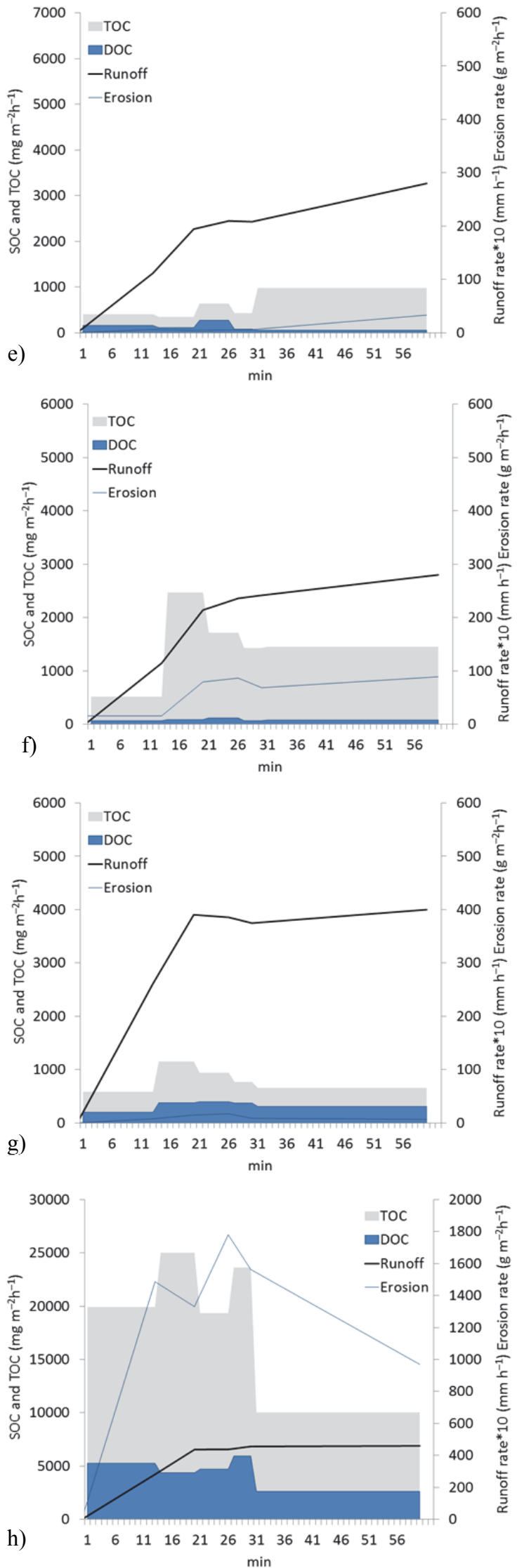

Fig. 3. Total organic carbon (TOC), dissolved organic carbon (DOC) sediment organic carbon $\left(\mathrm{S}_{\mathrm{d}} \mathrm{OC}\right)$, runoff rate and erosion rate during $1 \mathrm{~h}$ rainfall simulation $\left(50 \mathrm{~mm} \mathrm{~h}^{-1}\right)$ in: unaltered physical soil crust plot (Figure 3a); removed physical soil crust plot (Figure 3b); unaltered incipient cyanobacteria crust plot (Figure 3c); removed incipient cyanobacteria crust plot (Figure 3d); unaltered cyanobacteria crust plot (Figure 3e); removed cyanobacteria crust plot (Figure 3f); unaltered lichen crust plot (Figure 3g); removed lichen crust plot (Figure 3h). 
loss (Fig. 3). Biocrust removal triggered considerable $\mathrm{S}_{\mathrm{d}} \mathrm{OC}$ and TOC losses, even though $\mathrm{S}_{\mathrm{d}} \mathrm{OC}$ concentrations during rainfall were lower than the undisturbed biocrusts. The impact of biocrust removal was especially significant in lichen plots (Fig. $3 \mathrm{~h}$ ) in which DOC and $\mathrm{S}_{\mathrm{d}} \mathrm{OC}$ losses increased about 30 -fold over unaltered lichen plots at the start of rainfall, and then the difference in $\mathrm{S}_{\mathrm{d}} \mathrm{OC}$ decreased to about 20-fold higher and DOC about 8-fold higher where BSCs had been removed than in intact plots at the end of the rainfall.
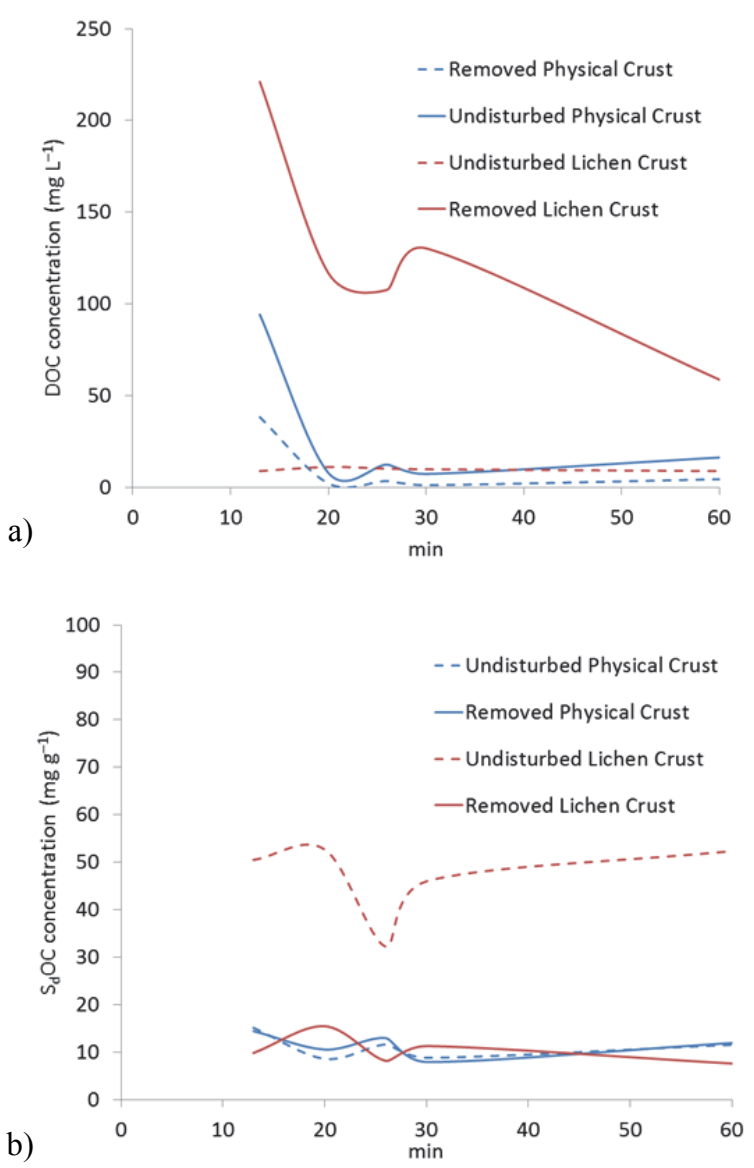

Fig. 4. Evolution of dissolved organic carbon (DOC) (Figure 4a) and sediment organic carbon $\left(\mathrm{S}_{\mathrm{d}} \mathrm{OC}\right)$ (Figure $4 \mathrm{~b}$ ) on four different plots (unaltered physical soil crust, removed physical soil crust, unaltered lichen crust, and removed lichen crust) during 1-h rainfall simulation $\left(50 \mathrm{~mm} \mathrm{~h}^{-1}\right)$.

\section{DISCUSSION \\ Dynamics of OC losses in biocrusts}

There is a long history of reports on the impact of erosion on water quality and nonpoint source pollution, while the research on dynamics of OC loss in relation to soil erosion is scarce. Even though erosion of soil OC is recognized as one of the main mechanisms of land degradation (Bationo et al., 2007; Lal, 2003), little is known about its impact on the soil C cycle (Maïga-Yaleu et al., 2013), and the lack of awareness is almost complete when soils are covered by biocrusts. Our results indicate that the presence of biocrusts decreased TOC loss substantially respecting to the physical soil crusts (Table 3 ), contributing to reducing land degradation, which is considered one of the main drivers of global change in arid and semiarid ecosystems (MEA, 2005). Average TOC losses from physical soil crusts were $7.83 \pm 3.27 \mathrm{~g} \mathrm{~m}^{-2}$, while from biologically crusted soils during an intense event, the total yield of OC from biocrusts was an average $1.80 \pm 1.86 \mathrm{~g} \mathrm{~m}^{-2}$ (ranging from $3.43 \pm$ $2.16 \mathrm{~g} \mathrm{~m}^{-2}$ for less developed biocrusts, i.e., incipient cyanobacteria, to $0.70 \pm 0.40 \mathrm{~g} \mathrm{~m}^{-2}$ for more developed biocrusts, i.e., lichens) (Table 3). This TOC represents a loss of only $0.24 \%$ of the surface OC (upper $1 \mathrm{~cm}$ ) on lichen plots, from $5 \%$ to $0.8 \%$ in cyanobacteria plots (incipient and developed respectively) and $13 \%$ on physical soil crusts. These measured OC mobilization rates are lower than those estimated by Kidron (2001) in Negev but in agreement with those found by Barger et al. (2006), who under simulated extreme rainfall, measured TOC losses of 0.9 to $7.9 \mathrm{~g} \mathrm{~m}^{-2}$ for intact late-successional dark cyanolichen crust and early-successional light cyanobacteria crust, respectively. Their results also coincide with ours with respect to biocrust development reducing TOC losses as a consequence of the widely demonstrated biocrust effects of reducing water erosion (Bowker et al., 2008; Chamizo et al., 2012a; Lázaro et al., 2008) and strongly contributing to nutrient retention (Delgado-Baquerizo et al., 2010; Chamizo et al., 2012b; Kidron et al., 2010). Cyanobacteria filaments and extracellular secretions act as gluing agents, binding soil particles and increasing the formation of soil aggregates, and thus increasing soil stability (Chamizo et al., 2010, 2012b; Chaudhary et al., 2009; Kidron et al., 2009; Zhao et al., 2014). Lichens, on one hand, have anchoring structures forming a cohesive mulch on the soil surface that strongly contributes to soil stability (Belnap, 2006; Belnap and Gardner, 1993), and on the other hand, grow above the soil surface, and thus provide soils with better protection from raindrop impact and detachment of particles during overland flow events than cyanobacteria (Belnap, 2006). Moreover, our results show that OC was lost primarily through sediment, especially from physical soil crusts and early successional stage biocrusts (such as incipient cyanobacteria) in which $\mathrm{S}_{\mathrm{d}} \mathrm{OC}$ represented over $95 \%$ of TOC. In more developed biocrusts, primarily in lichens, OC export by leaching (DOC) plays a significant role in TOC (36\%). However, although DOC represented a higher percentage of TOC losses in more than less developed crusts, DOC concentrations were higher in physical crusts than in biocrusts, probably because OC is more strongly retained by BSC structures, but more easily diluted in the soils devoid of them. On the contrary, $\mathrm{S}_{\mathrm{d}} \mathrm{OC}$ concentrations followed an opposite trend with increasing values from lichens to developed and incipient cyanobacteria and to physical crusts.

The high OC concentrations in runoff and sediments from unaltered biocrust plots during the first minutes of runoff can be explained by several factors. On the one hand, finer soil fractions, which are generally rich in OC contents (Lü et al., 2007), are mobilized first (Nadeu et al., 2010; Palis et al., 1997). On the other hand, developed biocrust surfaces are characteristically very rough (Rodríguez-Caballero et al., 2012), favoring atmospheric nutrient-enriched dust accumulation in the numerous microdepressions forming the biocrust surface (Reynolds et al., 2001; Verrecchia et al., 1995), which may be easily washed off by overland flow. Finally, raindrop impacts and runoff are able to disperse microorganisms, especially lichens and cyanobacteria living on the soil surface and the detached fragments are transported in runoff water. It has been reported that raindrop impacts are more efficient in transferring nutrient solutes than surface runoff (Fierer and Gabet, 2002), and peeling by raindrops is the prevailing mechanism for producing fine particles rich in $\mathrm{OC}$ at the beginning of rainfall, leading to high DOC concentrations. Once the depth of overland flow increases, the stripping effect of raindrops diminishes, and water runoff drives OC loss (Lü et al., 2007). 
The unusually high concentrations of $\mathrm{DOC}$ and $\mathrm{S}_{\mathrm{d}} \mathrm{OC}$ on physical soil crusts recorded in all plots at the beginning of rainfall (Fig. 4) can be attributed to fossil organic carbon released by weathering of outcropping sedimentary marls (Graz et al., 2012), given that the physical soil crust in this badland area covers a marl regolith and not a well-developed soil.

In summary, our data show that OC losses are driven by erosion (Fig. 2), and thus as overland flow and erosion from each plot increase, so does OC loss. Contrary to Barger et al. (2006), who found DOC losses were positively correlated with runoff, our data were related only indirectly with runoff, as high runoff rates on biocrusts are not always linked to high erosion rates (Cantón et al., 2011; Chamizo et al., 2012a). Thus lichen biocrusts yield the highest runoff rates (even higher than physical soil crusts in some cases) due to their hydrophobic properties (Souza-Egipsy et al., 2002; Tighe et al., 2012) and pore clogging (Kidron, 2014, Kidron et al., 1999; Rodríguez-Caballero et al., 2013), but in turn, strongly protect soils from water erosion, thereby reducing OC losses.

The results presented here may reflect the amount of OC dissolved in runoff and bonded to sediments that is likely to be displaced during an extreme storm from different types of soil crusts covering spaces among plants. Dissolved and sedimentbound OC removed by runoff from the crust patches is delivered to shrub patches, making this a critical process in maintaining plant productivity (Ludwig et al., 1997; Puigdefábregas, 2005). As pointed out by Brazier et al. (2014), "bare" intershrub areas act as suppliers of OC to shrub patches through runoff generation and erosion, and play vital roles in soil OC redistribution around the landscape and in increasing soil OC heterogeneity and ecosystem functioning (Ludwig et al., 2005). Hence OC losses presented here on a microplot scale would probably decrease significantly at large hillslope or catchment scales, as a consequence of $\mathrm{OC}$ redistribution. However, in areas where the small diameter of the plant patches does not provide an efficient barrier, runoff from biocrusts can bypass the shrubs (Kidron, 2011). Furthermore, the effectiveness of vegetation in trapping water and sediments is limited (Rodríguez-Caballero et al., 2014). Thus, at the beginning of any rainfall event, vegetated patches always act as runoff and sediment sinks, but their capacity for trapping these fluxes decreases over time, as the soil in those areas becomes saturated. Once the capacity to retain water and sediments is exceeded, water and sediment fluxes enriched in OC are transferred out of the system, reducing its productivity and its capacity for retaining water, sediments and nutrients in future rainfall events.

\section{Organic carbon dynamics after crust removal}

The strong increase in TOC losses after crust removal observed in this study is in agreement with those measured by other authors. Barger et al. (2006) reported TOC loss rates of about $2 \mathrm{~g} \mathrm{~m}^{-2}$ on dark cyanobacteria scraped plots, which are very similar to what we measured after removal of developed cyanobacteria biocrusts $\left(3.97 \mathrm{~g} \mathrm{~m}^{-2}\right)$. Li et al. (2008) measured TOC losses of about $3.2 \mathrm{~g} \mathrm{~m}^{-2}$ in plots where biocrusts and shrubs were altered. The rates we measured represent $7.5 \%$ of TOC loss in physical soil crust and from $3.17 \%$ to $13.59 \%$ in biocrusts (developed cyanobacteria and lichens, respectively). The highest impacts on DOC and TOC losses after crust removal occurred in the lichen plots. The lichen crusts generated the lowest erosion rates when unaltered, but the highest after their removal, thus resulting in the highest TOC losses. The way biocrusts modify soil surface and subsurface properties greatly depends on the type of biocrust. Thus, soil organic carbon con- tent in the first centimeters below the biocrust is higher under lichen than the other crusts (Chamizo et al., 2012b). Consequently, after lichen crust removal more organic carbon is available to be mobilized.

After crust removal, we found much higher TOC in all plots previously covered by biocrusts during the first half of the rainfall event (Fig. 3), later decreasing to a quasi-stable OC loss rate. TOC is probably limited by both detached material and transport (Frauenfeld and Truman, 2004). Sediment becomes less enriched in $\mathrm{OC}$ as time passes during an event, since the more carbon-rich fine aggregates are depleted early in the event (Jin et al., 2009; Palis et al., 1997; Polyakov and Lal, 2004; Wan and El-Swaify, 1998).

Biocrust loss increases water and wind erosion (Bowker et al., 2008; Chamizo et al., 2010, 2012a; Eldridge and Greene, 1994; Lázaro et al., 2008; McKenna-Neuman et al., 1996), triggering OC losses and reducing the capacity of soils to trap nutrient-enriched dust (Reynolds et al., 2001). Human disturbances in semiarid areas leading to biocrust disturbance alter the balanced transfer of OC to vegetated patches. During the first rainfall after disturbance, a higher input of OC to vegetated patches may be expected. But this "initial improvement" decreases over time as OC is washed away and a new structural physical soil crust is formed by raindrop impact on the disturbed plots, thus decreasing soil OC content. With further rainfall, higher runoff rates will be generated than over undisturbed biologically crusted surfaces. Moreover, destruction of biocrusts strongly accelerates erosion and nutrient exhaustion in the disturbed patches resulting in sediments impoverished in $\mathrm{OC}$, reducing the possible initial benefit. The consequent increase in runoff after disturbance once the soil seals and the biocrust is replaced by a physical soil crust, may cause part of the runoff water, sediments and nutrients, which in undisturbed conditions would have been trapped and stored in shrub patches, to run out of the system, increasing system connectivity and impairing its functioning, leading to a degraded system (Belnap et al., 2005).

\section{CONCLUSIONS}

The results of this study are twofold, on one hand, OC losses from water erosion of physical crusts and biocrusts during an extreme rainfall event were quantified, and on the other, the effects of biocrust disturbance (removal) on OC losses were found. Given that physical and biological crusts are globally widespread in semiarid and arid zones and comprise large areas of non-vegetated soil, the implications of both issues are relevant to storage, losses and spatial variability of soil OC in these ecosystems.

In view of our results, we can conclude that biocrusts reduce soil OC losses compared to bare or physically encrusted soils. Moreover, TOC mobilization depends on the type of biocrust, the more developed biocrusts being the most efficient in reducing TOC losses.

Most soil OC losses, as much from biocrusts as physical soil crusts, are bonded to sediments $\left(\mathrm{S}_{\mathrm{d}} \mathrm{OC}\right)$ and consequently erosion controls TOC, while no significant direct effect of runoff on OC losses was found. Only on undisturbed developed biocrusts, characterized by low erosion rates and $\mathrm{S}_{\mathrm{d}} \mathrm{OC}$, did DOC represent an important percentage of TOC. The highest DOC and $\mathrm{S}_{\mathrm{d}} \mathrm{OC}$ concentrations were recorded during the first minutes of rainfall and decreased with time due to washing of fine particles by runoff and depletion of associated OC. This suggests that short intense rainstorms are the main drivers of soil OC mobilization. 
Coinciding with previous studies, we found that TOC losses dramatically increased after crust removal. The highest impacts on DOC and $\mathrm{S}_{\mathrm{d}} \mathrm{OC}$ losses after crust removal occurred in lichen biocrusts, where their removal caused the highest increase in erosion. Above all, our findings highlight the importance of areas covered by biocrusts as key contributors to soil OC heterogeneity in arid and semiarid areas and their major role as water and OC suppliers through runoff to adjacent vegetation. Loss of biocrusts due to disturbances results in accelerated loss of water, sediments and associated OC, which can exceed the capacity of vegetation to retain these vital sources, especially during rain events of high intensity or high magnitude. Under this disturbed scenario, the predicted fate would be the flow of such sources out of the ecosystem, reducing their functioning and productivity.

Acknowledgements. This work was partially supported by several research projects: COSTRAS (RNM 3614), funded by the Consejería de Innovación, Ciencia y Empresa (Junta de Andalucía) including ERD (European Union of Regional Development) Funds, BACARCOS (CGL2011-29429) funded by Spanish national Plan for Research, Development and Innovation and including European Union of Regional Development Funds ERDF funds. The authors would like to thank Alfredo Durán and Montse Guerrero for their field and laboratory work assistance, and the property owner of El Cautivo, the Viciana family, is specially thanked for grating permissions to use their land as a scientific experimental site.

\section{REFERENCES}

Almagro, M., López, J., Boix-Fayos, C., Albaladejo, J., Martínez-Mena, M., 2010. Belowground carbon allocation patterns in a dry Mediterranean ecosystem: A comparison of two models. Soil Biol.Biochem., 42, 1549-1557.

Barger, N.N., Herrick, J.E., Van Zee, J., Belnap, J., 2006. Impacts of biological soil crust disturbance and composition on $\mathrm{C}$ and $\mathrm{N}$ loss from water erosion. Biogeochemistry, 77, 247-263.

Bationo, A., Kihara, J., Vanlauwe, B., Waswa, B., Kimetu, J., 2007. Soil organic carbon dynamics, functions and management in West African agro-ecosystems. Agricultural Systems, 94, 13-25.

Belnap, J., Gardner, J.S., 1993. Soil microstructure in soils of the Colorado Plateau. The role of the cyanobacterium Microcoleus vaginatus. Great Basin Naturalist, 53, 40-47.

Belnap, J., 2003. Microbes and microfauna associated with biological soil crusts. In: Belnap, J., Lange O.L. (Eds.): Biological Soil Crusts: Structure, Function, and Management. Revised 2nd printing. Springer, Berlin.

Belnap, J., Eldridge, D.J., 2003. Disturbance and recovery of biological soil crusts. In: Belnap, J., Lange, O.L. (Eds): Biological Soil Crusts: Structure, Function, and Management. Revised 2nd printing. Springer, Berlin.

Belnap, J., Welter, J.R., Grimm, N.B., Barger, N., Ludwig, J.A., 2005. Linkages between microbial and hydrologic processes in arid and semiarid watersheds. Ecology, 86, 298-307.

Belnap, J., 2006. The potential roles of biological soil crusts in dryland hydrologic cycles. Hydrol. Process., 20, 3159-3178.

Bowker, M.A., Belnap, J., Bala Chaudhary, V., Johnson, N.C., 2008. Revisiting classic water erosion models in drylands: The strong impact of biological soil crusts. Soil Biol. Biochem., 40, 2309-2316.

Brazier, R.E., Turnbull, L., Wainwright, J., Bol, R., 2014. Carbon loss by water erosion in drylands: Implications from a study of vegetation change in the south-west USA. Hydrol. Process., 28, 2212-2222.

Calvo-Cases, A., Gisbert, B., Palau, E., Romero, M., 1988. Un simulador de lluvia de fácil construcción. [Rainfall simulator of simple construction]. In: Sala, M., Gallart, F. (Eds.): Métodos y técnicas para la medición en el campo de procesos geomorfológicos. [Methods and techniques for field measurement of geomorphological processes]. Vol. 1. Sociedad Española de Geomorfología, Zaragoza. (In Spanish.)

Cantón, Y., Domingo, F., Solé-Benet, A., Puigdefábregas, J., 2001. Hydrological and erosion response of a badlands system in semiarid SE Spain. J. Hydrol., 252, 65-84.

Cantón, Y., Domingo, F., Solé-Benet, A., Puigdefábregas, J., 2002. Influence of soil-surface types on the overall runoff of the Tabernas badlands (south-east Spain): Field data and model approaches. Hydrol. Process., 16, 2621-2643.

Cantón, Y., Solé-Benet, A., Lázaro, R., 2003. Soilgeomorphology relations in gypsiferous materials of the Tabernas Desert (Almería, SE Spain). Geoderma, 115, 193222.

Cantón, Y., Del Barrio, G., Solé-Benet, A., Lázaro, R., 2004. Topographic controls on the spatial distribution of ground cover in the Tabernas badlands of SE Spain. Catena, 55, 341-365.

Cantón, Y., Solé-Benet, A., de Vente, J., Boix-Fayos, C., CalvoCases, A., Asensio, C., et al., 2011. A review of runoff generation and soil erosion across scales in semiarid southeastern Spain. J. Arid Environ., 75, 1254-1261.

Chamizo, S., Rodríguez-Caballero, E., Miralles-Mellado, I., Afana, A., Lázaro, R., Domingo, F., et al., 2010. Characteristics of physical and biological soil crusts with high influence in infiltration and erosion in Mediterranean ecosystems. Pirineos, 165, 69-96.

Chamizo, S., Cantón, Y., Lázaro, R., Solé-Benet, A., Domingo, F., 2012a. Crust composition and disturbance drive Infiltration through biological soil crusts in semiarid ecosystems. Ecosystems, 15, 148-161.

Chamizo, S., Cantón, Y., Miralles, I., Domingo, F., 2012 b. Biological soil crust development affects physicochemical characteristics of soil surface in semiarid ecosystems. Soil Biol. Biochem., 49, 96-105.

Chaudhary, V.B., Bowker, M.A., O'Dell, T.E., Grace, J.B., Redman, A.E., Rillig, M.C., et al., 2009. Untangling the biological contributions to soil stability in semiarid shrublands. Ecol. Appl., 19, 110-122.

Delgado-Baquerizo, M., Castillo-Monroy, A.P., Maestre, F.T., Gallardo, A., 2010. Changes in the dominance of $\mathrm{N}$ forms within a semi-arid ecosystem. Soil Biol. Biochem., 42, 376378.

Eldridge, D.J., Greene, R.S.B., 1994. Microbiotic soil crusts: A review of their roles in soil and ecological processes in the rangelands of Australia. Aust. J. Soil Res., 32, 389-415.

Eldridge, D.J., Zaady, E., Shachak, M., 2000. Infiltration through three contrasting biological soil crusts in patterned landscapes in the Negev, Israel. Catena, 40, 323-336.

Fierer, N.G., Gabet, E.J., 2002. Carbon and nitrogen losses by surface runoff following changes in vegetation. J. Environ. Qual., 31, 1207-1213.

Forrester, D.I., Bauhus, J., Cowie, A.L., 2006. Carbon allocation in a mixed-species plantation of Eucalyptus globulus and Acacia mearnsii. For. Ecol. Manage., 233, 275284. 
Frauenfeld, B., Truman, C., 2004. Variable rainfall intensity effects on runoff and interrill erosion from two Coastal Plain Ultisols in Georgia. Soil Sci., 169, 143-154.

Graz, Y., Di-Giovanni, C., Copard, Y., Mathys, N., Cras, A., Marc, V., 2012. Annual fossil organic carbon delivery due to mechanical and chemical weathering of marly badlands areas. Earth Surf. Process. Landforms., 37, 1263-1271.

Jin, K., Cornelis, W.M., Gabriels, D., Baert, M., Wu, H.J., Schiettecatte, W., et al., 2009. Residue cover and rainfall intensity effects on runoff soil organic carbon losses. Catena, 78, 81-86.

Kidron, G.J., 2001. Runoff-induced sediment yield over dune slopes in the Negev Desert. 2: Texture, carbonate and organic matter. Earth Surf. Process. Landforms., 26, 583599.

Kidron, G.J., 2011. Runoff generation and sediment yield on homogeneous dune slopes: scale effect and implications for analysis. Earth Surf. Process. Landforms., 36, 1809-1824.

Kidron, G.J., 2014. Sink plot for runoff measurements on semiflat terrains: hydrological and ecological implications. J. Hydrol. Hydromech., 4, 303-308.

Kidron, G.J., Yaalon, D.H., Vonshak, A., 1999. Two causes for runoff initiation on microbiotic crusts: hydrophobicity and pore clogging. Soil Sci., 164, 18-27.

Kidron, G.J., Vonshak, A., Abeliovich, A., 2009. Microbiotic crusts as biomarkers for surface stability and wetness duration in the Negev Desert. Earth Surf. Process. Landforms., 34, 1594-1604.

Kidron, G.J., Vonshak, A., Dor, I., Barinova, S., Abeliovich, A., 2010. Properties and spatial distribution of microbiotic crusts in the Negev Desert, Israel. Catena, 82, 92-101.

Lal, R., 2003. Soil erosion and the global carbon budget. Environ. Int., 29, 437-450.

Lázaro, R., Cantón, Y., Solé-Benet, A., Bevan, J., Alexander, R., Sancho, L.G., et al., 2008. The influence of competition between lichen colonization and erosion on the evolution of soil surfaces in the Tabernas badlands (SE Spain) and its landscape effects. Geomorphology, 102, 252-266.

Li, X.J., Li, X.R., Song, W.M., Gao, Y.P., Zheng, J.G., Jia, R.L., 2008. Effects of crust and shrub patches on runoff, sedimentation, and related nutrient $(\mathrm{C}, \mathrm{N})$ redistribution in the desertified steppe zone of the Tengger Desert, Northern China. Geomorphology, 96, 221-232.

Lichner, L., Holko, L., Zhukova, N., Schacht, K., Rajkai, K., Fodor, N., et al., 2012. Plants and biological soil crust influence the hydrophysical parameters and water flow in an aeolian sandy soil. J. Hydrol. Hydromech., 60, 309-318.

Litton, C.M., Ryan, M.G., Knight, D.H., 2004. Effects of tree density and stand age on carbon allocation patterns in postfire lodgepole pine. Ecol. Appl., 14, 460-475.

Lü, Y., Fu, B., Chen, L., Liu, G., Wei, W., 2007. Nutrient transport associated with water erosion: Progress and prospect. Prog. Phys. Geogr., 31, 607-620.

Ludwig, J.A., Tongway, D.J., Freudenberger, D., Noble, J., Hodgkinson, K., 1997. Landscape ecology function and management: Principles from Australia's Rangelands. CSIRO Publications, Collingwood, Australia.

Ludwig, J.A., Wilcox, B.P., Breshears, D.D., Tongway, D.J., Imeson, A.C., 2005. Vegetation patches and runoff-erosion as interacting ecohydrological processes in semiarid landscapes. Ecology, 86, 288-297.

Maïga-Yaleu, S., Guiguemde, I., Yacouba, H., Karambiri, H., Ribolzi, O., Bary, A., et al., 2013. Soil crusting impact on soil organic carbon losses by water erosion. Catena, 107, 26-34.
Martinez-Mena, M., Lopez, J., Almagro, M., Boix-Fayos, C., Albaladejo, J., 2008. Effect of water erosion and cultivation on the soil carbon stock in a semiarid area of South-East Spain. Soil Till. Res., 99, 119-129.

McKenna Neuman, C., Maxwell, C.D., Boulton, J.W., 1996. Wind transport of sand surfaces crusted with photoautotrophic microorganisms. Catena, 27, 229-247.

Millennium Ecosystem Assessment (MEA), 2005. Drylands Systems. Chapter 22. In: Ecosystems and Human Wellbeing: Current State and Trends, Volume 1. Island Press, Washington, DC.

Mingorance, M.D., Barahona, E., Fernández-Gálvez, J., 2007. Guidelines for improving organic carbon recovery by the wet oxidation method. Chemosphere, 68, 409-413.

Miralles-Mellado, I., Cantón, Y., Solé-Benet, A., 2011. Twodimensional porosity of crusted silty soils: Indicators of soil quality in semiarid rangelands? Soil Sci. Soc. Am. J., 75, $1330-1342$.

Nadeu, E., Noix-Fayos, C., De Vente, J., López, J., MartínezMena, M., 2010. Organic carbon mobilization by different erosive processes in the slope-channel connection. Pirineos, 165, 157-177.

Palis, R.G., Ghandiri, H., Rose, C.W., Saffigna, P.G., 1997. Soil erosion and nutrient loss. III. Changes in the enrichment ratio of total nitrogen and organic carbon under rainfall detachment and entrainment. Aust. J. Soil Res., 35, 891-905.

Polyakov, V.O., Lal, R., 2004. Soil erosion and carbon dynamics under simulated rainfall. Soil Sci., 169, 590-599.

Puigdefábregas, J., 2005. The role of vegetation patterns in structuring runoff and sediment fluxes in drylands. Earth Surf. Process. Landforms., 30, 133-147.

Quinton, W.L., Pomeroy, J.W., 2006. Transformations of runoff chemistry in the Arctic tundra, Northwest Territories, Canada. Hydrol. Process., 20, 2901-2919.

Reynolds, R., Belnap, J., Reheis, M., Lamothe, P., Luiszer, F., 2001. Aeolian dust in Colorado Plateau soils: Nutrient inputs and recent change in source. Proc. Natl. Acad. Sci. U.S.A., 98, 7123-7127.

Rodríguez-Caballero, E., Cantón, Y., Chamizo, S., Afana, A., Solé-Benet, A., 2012. Effects of biological soil crusts on surface roughness and implications for runoff and erosion. Geomorphology, 145-146, 81-89.

Rodríguez-Caballero, E., Cantón, Y., Chamizo, S., Lázaro, R., Escudero, A., 2013. Soil loss and runoff in semiarid ecosystems: A complex interaction between biological soil crusts, micro-topography, and hydrological drivers. Ecosystems, 16, 529-546.

Rodríguez-Caballero, E., Cantón, Y., Lazaro, R., Sole-Benet, A., 2014. Cross-scale interactions between surface components and rainfall properties. Non-linearities in the hydrological and erosive behaviour of semiarid catchments. J. Hydrol., 517, 19, 815-825.

Souza-Egipsy, V., Ascaso, C., Sancho, L.G., 2002. Water distribution within terricolous lichens revealed by scanning electron microscopy and its relevance in soil crust ecology. Mycol. Res., 106, 1367-1374.

Tighe, M., Haling, R.E., Flavel, R.J., Young, I.M., 2012. Ecological succession, hydrology and carbon acquisition of biological soil crusts measured at the micro-scale. PLoS ONE, 7, e48565.

Verrecchia, E., Yair, A., Kidron, G.J., Verrecchia, K., 1995. Physical properties of the psammophile cryptogamic crust and their consequences to the water regime of sandy soils, north-western Negev Desert, Israel. J. Arid Environ., 29, 427-437. 
Wan, Y., El-Swaify, S.A., 1998. Sediment enrichment mechanisms of organic carbon and phosphorus in a wellaggregated Oxisol. J. Environ. Qual. 27, 132-138.

Warren, S.D., 2003. Synopsis: Influence of biological soil crusts on arid land hydrology and soil stability. In: Belnap, J., Lange, O.L. (Eds.): Biological Soil Crusts: Structure, Function, and Management. Revised 2nd printing. Springer, Berlin.

Whitford,W.G., 2002. Ecology of Desert Systems. Academic Press, San Diego, CA.

Zhao, Y., Qin, N., Weber, B., Xu, M., 2014. Response of biological soil crusts to raindrop erosivity and underlying influences in the hilly Loess Plateau region, China. Biodivers. Conserv., 23, 1669-1686.

Received 12 June 2014

Accepted 18 July 2014

Note: Colour version of Figures can be found in the web version of this article. 